\title{
DURATION AND RECURRENCE IN UNEMPLOYMENT BENEFITS
}

\author{
José M. Arranz and Carlos García-Serrano \\ (Universidad de Alcalá, Spain)
}

Draft: $28 / 12 / 2012$

\begin{abstract}
:
Using administrative data for the period 2005-2010, we investigate duration and recurrence in unemployment benefits in Spain. The results suggest the existence of (at least) three groups of individuals, each one with different combinations of covered unemployment duration and recurrence. We also find that the impact of the economic crisis has been to increase the duration and the recurrence in unemployment benefits. Our findings support the hypothesis that not only the heterogeneity but also the previous experience of unemployment benefit increase the expected duration in subsequent benefit periods.
\end{abstract}

JEL classification: C41, J64, J65

Key words: unemployment benefits, recurrence, duration models, administrative data

Acknowledgements:

José M. Arranz acknowledges financial support by the Ramón Areces Foundation and Carlos García-Serrano by the Ministry of Science and Innovation (National Plan, ECO2010-19963). The authors wish to thank the Spanish Social Security for providing the data for this research. Obviously, the opinions and analyses are the responsibility of the authors. The usual disclaimer applies. 


\section{Introduction}

The unemployment rate in Spain has rocketed from 8\% in 2007 to 25\% in 2012, so the number of unemployed individuals increased from about 1.8 million to nearly 6 million according to the Labour Force Survey (LFS). On the other hand, information coming from the registers of the Public Employment Service (PES) shows that the number of registered unemployed increased from about 2 million in 2007 to nearly 5 million at the end of 2012; not all of them were entitled to receive unemployment benefits, the number of these ranging from less than 1.5 million in a given month of 2007 to about 3 million in a given month of 2012. These figures are a serious problem not only for the economy but also for the public finance in general and the sustainability of the expenditure on the unemployment compensation system (UCS) in particular. They call for a profound analysis of entries into and exits from unemployment benefit and how they have evolved over time.

In examining individual joblessness, most studies have focused solely on unemployment duration. However, the duration of a spell of unemployment might be considered a poor indicator of the joblessness experience in a period of time. This implies that recurrence (the re-incidence of individuals into unemployment over time) should be considered as well, since it is possible that a non-negligible portion of unemployment is accounted for by a relatively numerous group of workers with several spells in a given time interval (Clark and Summers, 1979; Winter-Ebmer and Zweimüller, 1992).

Understanding whether the costs of unemployment, particularly repeated unemployment, are persistent and what circumstances may influence that persistence is an important step toward developing policies to fight joblessness. If labour market turnover is high and mean duration of employment spells is reduced, active labour market programmes may be inefficient because they may move the unemployed into work in the short-term but those workers may also return quickly to joblessness. In other words, for such policy to be efficient it requires the unemployed who find a job to remain in employment longer.

Some studies have focused attention on the analysis of the determinants of duration of covered unemployment using information on only one individual spell in Spain (for instance, Alba-Ramirez, 1999, and Bover et al., 2002, with the LFS; Jenkins and García-Serrano, 2004, Arranz and Muro, 2004a with administrative data from the PES). However, very few have examined the phenomenon of the existence of multiple 
spells of unemployment benefit receipt. Cebrián et al. (1995), with data for the period 1984-1991, found the existence of a high level of recurrent unemployment: about 30 per cent of recipients re-appeared again in the UCS within two years and more than 50 per cent within four years. Arranz and Muro (2004b), focusing on individuals aged less than 35 , showed that the proportion of recurrence in unemployment benefits (two years) was nearly 33\% in 1987 and 1995 with a peak of $38.5 \%$ in 1991.

High worker turnover (based on the wide use of temporary contracts after the 1984 labour market reform and the possibility of linking short-term employment contracts with subsequent spells of unemployment benefit) was probably one of the potential reasons for the financial strains of the UCS, which led the government to pass a reform in 1992 (see Arranz et al., 2009). Under the then new regulation, eligibility to UI was tightened and UA widened. In particular, it increased the minimum contribution period required to gain access to UI (from 6 to 12 months), reduced the entitlement obtained with a given contribution period and cut the UI replacement rates -from $80 \%$ of the base wage to $70 \%$ during the first six months of entitlement and from $70 \%$ to $60 \%$ from the seventh month onwards. At the same time, although the extension of the minimum contribution period potentially made that more people entered the UA system, the criteria was tightened ${ }^{1}$. Something similar has occurred under the ongoing recession, when expenditure on unemployment compensation rocketed in 2009-2010 and maintained in high levels in 2011-2012, and a new regulation has been passed which includes a reduction of the UI replacement rates (from $60 \%$ to $50 \%$ from the seventh month onwards) and more tighten means-tested criteria to access to UA. Again, one of the objectives of the reform is to contribute to reduce the expenditure in the UCS.

It is in this context in which our work should be understood. The aims of the paper are to examine whether it is true that unemployment may be characterised by the existence of a large group of workers with long durations in the receipt of benefits and other, less numerous group incurring in more recurrence in compensated unemployment and shorter durations, and to investigate the factors associated with the duration and recurrence in the receipt of unemployment benefits in Spain.

To reach this objective, we use an administrative database: the "Continuous Sample of Working Life" (Muestra Continua de Vidas Laborales, MCVL hereinafter).

\footnotetext{
${ }^{1}$ Arranz et al. (2009) show that these legislative changes had a positive though modest effect on the transition rates from unemployment.
} 
In order to carry out this analysis, we define an observation window of equal length for two periods: one of expansion years (2005-2007) and other of recession years (20082010). In particular, we select the individuals who start the receipt of an unemployment benefit anytime during the first quarter of 2005 and 2008, respectively, and followed them up until the end of the observation window 31 ${ }^{\text {st }}$ December 2007 and 2010, respectively.

A duration model is estimated for three groups of recipients who exit to a (longterm) job without coming back again to the UCS, to a (short-term) job returning again to the UCS (individuals with multiple incidences) or to uncovered unemployment after exhausting unemployment benefits. We also estimate a duration model for recipients with multiple unemployment benefit spells. Multiple occurrences may occur because there are multiple observations of the same kind. In these cases is reasonable assume that the hazard is the same for all spells for the same individual.

The paper is organized as follows. Section 2 briefly describes the theoretical arguments set forth to explain repeated joblessness. Section 3 gives a description of the dataset and undertakes a detailed descriptive analysis in order to find out the characterization of unemployment benefit according to recurrence and duration. Section

4 presents the duration model, while section 5 offers the empirical results. Finally, we summarize our findings in section 6.

\section{Theoretical explanations}

Duration and repeated unemployment can be approached theoretically from different perspectives. In the first place, the job search theory (Mortensen, 1977) provides a framework for the discussion of the factors that affect the probability of receiving job offers and the probability of accepting it. An important prediction of this theory is that, for a given wage offer distribution, since the reservation wage rises with the level of unemployment benefit, increases in unemployment compensation lead to a reduced probability of making the transition from unemployment to employment. However, this conclusion has to be qualified if we take account of the fact that benefit entitlement is limited (so the reservation wage of a UI recipient falls with the length of the unemployment spell until maximum entitlement is reached) and that eligibility depends on past insured employment (so return to employment means that the individual re-qualifies for benefit). The latter feature means that UI makes the transition 
to employment more attractive, so UI may have positive as well as negative effects on the transition from unemployment to employment (Atkinson and Mickelwright, 1991).

In sum, job search theory looks at workers' mobility and at any intervening spell of unemployment as a productivity activity (Jovanovic, 1979; Mortensen, 1988) and can explain part of the "frictional" unemployment as a productive time spent on searching for an optimal job offer but are less successful in explaining the incidence of multiple spells of unemployment (Pissarides, 1985).

Segmentation or dual labour market theory describe two segments with different employment and wage conditions, with competition being possible within but not between segments (Piore, 1971). External mobility from primary labour market will therefore be infrequent and voluntary; moves should really pay and give access to even better job ladders. On the contrary, workers in the secondary labour market move across jobs that do not define ascending chains; job interruptions are likely to be involuntary and associated with spells of unemployment so that no improvement in wages is expected from them. In that context, the instability of jobs in the secondary labour market (in particular, among young and less-skilled workers) in connection with seasonal factors and disincentive effects are some reasons for potential recurrence in the receipt of unemployment benefits (Steiner, 1988).

Other perspectives focus on the issue of state dependence ${ }^{2}$. Past unemployment experiences may determine future unemployment prospects (Heckman and Borjas, $1980)^{3}$. Two types of explanations have been offered to interpret the correlation between past and current unemployment periods: the spurious and the true state dependence $^{4}$. The first explanation is based on the fact that individuals differ in certain unobserved characteristics that influence their probability to experience unemployment in the future, which in turn is not influenced by their past unemployment experience.

\footnotetext{
${ }^{2}$ Despite the different picture of unemployment when recurrent spells are taken into account, most studies have focused attention on the effect of past unemployment (scarring effects) on unemployment. For instance, Heckman and Borjas (1980), Lynch (1989) and Omori (1997) with US data; Trivedi and Alexander (1989) with Australian data; Roed et al. (1999) using Norwegian data; Arulampalam et al. (2000) and Gregg (2001) with British data; Mühleisen and Zimmerman (1994) and Flaig et al. (1993) with German data; Steiner (1989) and Winter-Ebmer and Zweimüller(1992) with Austrian data; and Arranz and Muro (2004b) with Spanish data.

${ }^{3}$ The hypothesis that the unemployment process depends on its past history is referred to as "hysteresis" in the macroeconomic literature (see Blanchard and Summers, 1986).

${ }^{4}$ Heckman and Borjas (1980) were the first to distinguish state dependence in three forms: dependence in the current duration (duration dependence), dependence in the occurrence (occurrence dependence) and dependence on the duration of the past labour market experiences (lagged duration dependence). These types of state dependence are named in the literature as true state dependence, where most subsequent works (Omori, 1997; Arulampalam et al., 2000, etc.) have focused on the lagged duration dependence.
} 
The true state dependence explanation indicates that past unemployment experience has a genuine behavioural effect in the sense that an otherwise identical individual who did not experience unemployment would behave differently in the future than an individual who had experienced unemployment. Then, workers with higher mobility and multiple unemployment incidences may be offered less secure jobs because they lose valuable work experience while unemployed (Phelps, 1972) or because employers use unemployment experience as a signal of low productivity (Lockwood, 1991; Pissarides, 1992) reducing their future probability of getting a job ${ }^{5}$.

\section{Data and descriptive analysis}

\subsection{The dataset}

The MCVL provides information every year since 2004 based on the records of the Spanish Social Security, combined with personal data from the Continuous Municipal Register and, in some versions, tax data from the National Revenue Agency. The population of reference in the MCVL includes both employed workers who are registered with the Social Security and recipients of contributory and non-contributory pensions and unemployment benefits ${ }^{6} .4$ percent of this population are selected by means of a simple random sampling system ${ }^{7}$. The resulting database thus provides annual information on more than one million people who have had any kind of relationship with the Social Security in a given year.

This dataset includes information on individual characteristics, firms and job attributes. It also provides information on the unemployment benefits received by each worker in the event they were separated from their jobs and eligible for them: whether each individual was receiving unemployment benefits when out of work, the type of benefits received (UI or UA) and the number of days of benefit receipt.

\footnotetext{
${ }^{5}$ Some authors point out that this apparent negative relationship between unemployment duration and employment prospects can have a reverse causation: rather than having poor job prospects because individuals become long-term unemployed, individuals are long-term unemployed because they have poor job prospects (Roed et al., 2009).

${ }^{6}$ Jobseekers not receiving benefits and inactive population (as distinct from pensioners) are not included. The same applies to workers with a social welfare system other than the Social Security (civil servants receiving pensions) and those with none (such as those working in the informal or submerged economy or some marginal activities).

${ }^{7}$ Simple random sampling is used to generate the MCVL (without any kind of stratification), selecting people from the annual reference population whose personal identification code contains randomly selected figures in a determined order. These figures are identical every year. This method guarantees that the same people are selected, as long as they continue to be registered with the Social Security system, and also ensures that new entrants are representative of the registered population.
} 
Furthermore, this administrative dataset has a longitudinal design. From 2004 onwards, an individual who is present in an edition of the sample and subsequently remains registered with the Social Security stays as a sample member. The sample is refreshed with new sample members, remaining representative of the population in each edition. Therefore, its longitudinal nature makes it possible to know the labour market status of a given individual after a job separation has taken place: recipient of unemployment benefits, non-recipient and other situation. Unfortunately, the data base does not contain information on the entitlement period (however, it does on previous employment duration, a proxy variable for entitlement duration).

\subsection{Descriptive analysis: total number of spells of benefits and individuals (recipients)}

Our first step consists of giving information on the number of spells of receipt of unemployment benefits that began annually during the period 2004-2010. Table 1 provides this information by previous labour relation. We have followed the process developed by Arranz et al. (2012) through which the original information of the MCVL data source can be organized in such a way as to permit the accurate study of work histories ${ }^{8}$.

\section{[Insert Table 1]}

As can be observed, the number of spells starting each year is enormous: 3.5 million in 2004, 4.2 million in 2007 and, as a consequence of the recession, 5.7 million in 2008 and 9.8 million in $2010^{9}$. These figures must be put in contrast with other labour market variables in order to have a correct idea of its size. Bear in mind, for instance, that the workforce was above 20 million in 2004 and over 23 million from 2008 onwards, and that the stock of recipients of unemployment benefits in a given month was less than 1.3 million in 2004-2005 and 3 million in 2010.

Most of the spells of recipiency (about 80 percent) in a given year of the period 2004-2008 start after the end of an employment spell, while the rest begin after the exhaustion of previous unemployment benefits (either UI or UA). These proportions

\footnotetext{
${ }^{8}$ These authors show the sample loss and bias which occurs when data regarding spells and individuals included in the database are not processed correctly. They propose a procedure for processing the sample that we follow step by step.

${ }^{9}$ These data generally coincide with those provided by the Public Employment Office (Annual Report on Labour Statistics). Thus, our procedure for processing the MCVL obtains quite accurate information regarding the process of registering unemployment benefit recipients. It should be borne in mind that the PES does not include the agricultural subsidy in their figures and that it may conduct some additional
} 
were altered in 2009 and 2010 due the rising number of spells due to short-time work, after the passing by the government of measures increasing the incentives for firms and workers to use short-time work instead of layoffs as an alternative to adjusting to reduced product and labour demand.

We now proceed to select a sample of individuals starting their spells of receipt of unemployment benefits in a given year (2005 and 2008) and then follow them up through time (for about three years, until the end of 2007 and 2010, respectively). This will allow us to know how many people exhibit only one incidence of entry into the UCS within the window of observation and how many exhibit several incidences, with successive spells of employment and benefits (they may be consecutive, for instance, a UI benefit which runs out followed by a UA benefit). In addition, in order to make the sample homogeneous, we select recipients between 16 and 64 years-old (in the year of the first incidence) receiving UI due to the ending of a labour relationship (because of a layoff, end of temporary contract, etc.).

Table 2 provides the mean and the distribution of durations of benefits for spells starting in 2005 and 2008. The first and second grand columns refer to equal periods of observation characterized by distinct economic conditions: an upswing (2005-2007) and a downswing (2008-2010). We distinguish two types of covered unemployment duration: one is computed from the information on spells and the other from the information on individuals. The information shown in the columns labeled "Spells" refers to the duration of the spells of covered unemployment, while that shown in the columns labeled "Individuals" refers to the effective duration of covered unemployment of persons (corresponding to the first incidence of covered unemployment within the year).

On the one hand, the duration of the spells of unemployment benefits starting each year does not distinguish whether they correspond to the same person or not (and, in the first case, whether they are consecutive or not). This duration is calculated dividing the total duration of the spells of unemployment benefits starting in a given period by the total number of spells. On the other hand, the duration of the (aggregate) spells of unemployment benefits of the same person will be called "the unemployment benefits duration of individuals". This duration is calculated taking into account that the spells

processing (for example, processing administrative errors in variables such as gender, cause of termination, year of birth, etc.) which is not conducted in our case. 
pertaining to the same person are aggregated when they are consecutive, i.e. without an employment spell in between.

If a person has a spell of UI starting in 2008 followed by a spell of UA, we consider that they make up one incidence in covered unemployment of the same person (in this case, with two spells of consecutive covered unemployment, so the duration of both are added up). The same procedure is applied when a person links two consecutive spells of UA. The effective average duration of covered unemployment of each person is computed as the sum of the first incidence (sum of one or more consecutive spells of unemployment benefits) divided by the total number of persons having this first incidence.

\section{[Insert Table 2]}

In what follows, we comment both perspectives and the distinction between the duration of spells and the duration of episodes of individuals to provide evidence on the duration of covered unemployment ${ }^{10}$. The number of spells starting in any moment of 2005 (2008) was 3,111,075 (5,087,375), which corresponds to 2,217,075 $(3,446,275)$ different persons. When we compare the mean, the median and the distribution of durations by type of scenario -spells or individuals-, what emerges is the existence of huge differences. Moreover, the change of the economic and labour market context has brought about important effects.

The mean and median durations of the spells of unemployment benefits initiated in a given year (first incidence in the UCS) are lower before the crisis than once the crisis began: 125 days vs. 141 days (mean) and 87 days vs. 96 days (median). Nevertheless, these figures are much lower than the effective duration of covered unemployment of individuals: 201 days and 250 days, respectively, on average, and 120 days and 143 days, respectively, on median.

These differences are emphasized when we focus on long-term covered unemployment. $10 \%$ of the individuals starting a benefit in 2005 and followed up until the end of 2007 remain in covered unemployment for more than 534 days, while the same proportion exhibit a duration of more than 282 days when we consider the information of spells. The effect of the economic crisis is clear, since these durations

\footnotetext{
${ }^{10}$ Arranz and García-Serrano (2012) show that the magnitude of the duration of unemployment benefit recipiency vary considerably when we use either spells or individuals data. They demonstrate empirically that the exit hazard rates from recipiency using spells' data are overestimated when compared to using individuals' data. Therefore, the expected duration of recipiency is underestimated.
} 
rise: $10 \%$ of the individuals (spells) starting a benefit in 2008 and followed up until the end of 2010 remain in covered unemployment for more than 716 days (334 days).

This information reveals that any analysis of the duration of covered unemployment focusing strictly on spells (not individuals) underestimates the "true" duration. These differences come from the fact that the durations of individuals are constructed adding up the information of consecutive spells of unemployment benefits. Given the evidence shown so far, in what follows we only use information on individuals, which allows us to exploit the longitudinal information of each person and compute the number of incidences per person in covered unemployment in a given period, the duration of each incidence and the total accumulated duration.

Now we turn to focus attention on those individuals starting a spell of receipt after the end of a labour relationship, which allows us to consider the same initial conditions of individuals ${ }^{11}$. Our aim is to know how many of them leave the UCS and do not come back during a long period of time (three years) and how many return.

In order to carry out this analysis, we define an observation window of equal length for two periods (2005-2007 and 2008-2010) and select the spells of benefits starting anytime during the first quarter of 2005 and 2008, respectively. In the first window, the individuals start a benefit anytime between the 1st of January 2005 and the 31st of March 2005, while their successive entries into the UCS may occur until the 31st of December 2007. In the second window, the individuals start a benefit anytime between the 1st of January 2008 and the 31st of March 2008, while their successive entries into the UCS may occur until the 31st of December 2010.

Table 3 contains the number of incidences in the UCS of job losers who started an unemployment benefit in the first quarter of 2005 and 2008. The recurrence we obtain is relatively high: $45 \%$ of individuals accessing the UCS from employment in 2005 entered only once and did not return to the UCS during the rest of the period (three years), while $55 \%$ re-entered (of these, $24 \%$ exhibited two incidences in the UCS, $13 \%$ three and $6.5 \%$ five or more). Recurrence in the receipt of unemployment benefits increased in 2008-2010: $36 \%$ of individuals entered and did not come back to the UCS anymore, while $64 \%$ entered again (of these, nearly $24 \%$ had two incidences, $15.5 \%$ three and about $10 \%$ five or more).

\footnotetext{
${ }^{11}$ Thanks to this selection we try to avoid the "initial conditions" (or length selection) bias in order to measure the duration of unemployment.
} 
Obviously, the duration of covered unemployment periods may vary depending on the number of entries of individuals into the UCS. Table 4 contains the distribution of the receipt of unemployment benefit by order of incidences. The results confirm the expectation that average (and median) duration of covered unemployment diminish with the number of incidences, being longer during the downswing.

\section{[Insert Table 3 and 4]}

As we mentioned above, there are individuals who enter the UCS and do not come back anymore in the period of observation while others re-enter, so the duration of their covered unemployment periods may be different. This fact may affect the average duration of the first incidence, since we include all individuals in its computation. To avoid this bias, Table 5 provides the distribution of the effective duration of the first incidence of the individuals starting a benefit after the loss of a job in the first quarter of 2005 and 2008, distinguishing between those who come back and those who do not come back to the UCS.

The mean duration of the covered unemployment periods of the individuals who do not return to the UCS is longer than those who return: 257 days (8.6 months) vs. 109 days (3.6 months) in 2005. These durations are longer for the spells starting in 2008: 349 days (11.6 months) vs. 122 days (4.1 months). The medians are substantially lower than the means. Moreover, $10 \%$ of the individuals who do not come back to the UCS exhibit durations longer than 669 days (22 months) if they entered in 2005 and longer than 918 days (31 months) if they entered in 2008.

\section{[Insert Table 5]}

These extremely long durations of the group of workers who only appear once in the UCS in the window frame stem from the individuals who do not return to employment and either their status after the recipiency of benefits is unknown (it can be uncovered unemployment or inactivity) or they remain in the UCS at the end of the period of observation. Obviously, the durations are much shorter in the case of the group of individuals who only appear once and return to employment after receiving benefits. This result underlines the existence of a relatively large group of workers with long joblessness durations that can hardly be considered unemployed. 


\section{Econometric model}

In order to carry out the empirical analysis in the next section, we specify two continuous time duration models. The first one is a frailty duration data model to examine the determinants of the first incidence of individuals who exit from unemployment benefits to find a job (or not) and do not return to the UCS anymore. The second one is a shared frailty duration data model for repeated incidences in unemployment benefits of individuals who find a job and come back to the UCS several times. Whilst in the former model information about first incidence in unemployment benefits is considered; the latter model includes information about all incidences of individuals with recurrences in unemployment benefits. The difference between shared and unshared frailty is the assumption of how frailty is distributed in the data. A frailty model is a heterogeneity model where the frailties are assumed to be individual (or spell) specific. A shared frailty model is a random effect where the frailties are shared (or common) among groups of individuals (or spells) and are randomly distributed across groups (see, Gutierrez, 2002; and Cleves, 2004). We will use the terminology of these authors to present both models.

\subsection{Unshared frailty model}

The unshared or individual frailty model defines the hazard function at time $t$ to for individual $j$ to be (Cleves et al., 2004) ${ }^{12}$

$$
h\left(t_{j} \mid x_{j}, \alpha_{j}\right)=\alpha_{j} h\left(t_{j} \mid x_{j}\right) \quad \mathrm{j}=1, \ldots, \mathrm{n} .
$$

Where $t$ is the current duration of unemployment benefits; $X$ are covariates and $\alpha_{j}$ is the unobserved observation-specific effect. This effect, $\alpha_{\mathrm{j}}$, is known as frailty term and represent that the individuals are heterogeneous in the population due to factors that remain unobserved. The frailty $(\alpha)$ is some random positive quantity not estimated from the data but instead assumed to have mean one (for purposes of identifiability) and variance $\theta$, that is estimated from the data. Given the relationship between the hazard and survivor functions, we can show from equation 1 that the individual survival function conditional on the frailty is

$$
S\left(t_{j} \mid x_{j}, \alpha_{j}\right)=\left\{S\left(t_{j} \mid x_{j}\right)\right\}^{\alpha_{j}} .
$$

\footnotetext{
12 The hazard function normally is represented as a baseline hazard function that is multiplicatively affected by the covariates and unobserved heterogeneity. We omit its representation because it's not necessary in the development that we follow.
} 
Where $S(t)$ is the survival function from a standard survival model and may include ancillary parameters and covariate effects. If $\alpha_{j}$ has probability density function $\mathrm{g}(\alpha)$, the unconditional survival function is

$$
S_{\theta}\left(t_{j} \mid x_{j}\right)=\int_{0}^{\infty}\left\{S\left(t_{j} \mid x_{j}\right)\right\}^{\alpha_{j}} g\left(\alpha_{j}\right) d \alpha_{j} .
$$

Where we use subscript $\theta$ to emphasize the dependence on the frailty variance $\theta$. Following Gutierrez (2002), the log-likelihood function is formed as a combination of the failures and censored observations as

$$
\begin{aligned}
& L n L=\ln \prod_{i=1}^{n} \frac{\left\{S_{\theta_{j}}\left(t_{j} \mid x_{j}\right)\right\}^{\left\lfloor-d_{j}\right.}\left\{f_{\theta_{j}}\left(t_{j} \mid x_{j}\right)\right\}^{d_{j}}}{S_{\theta_{j}}\left(t_{0 j} \mid x_{j}\right)}= \\
& =\sum_{i=1}^{n}\left[\ln \left\{S_{\theta_{j}}\left(t_{j} \mid x_{j}\right)\right\}-\ln \left\{S_{\theta j}\left(t_{0 j} \mid x_{j}\right)\right\}+d_{j} h_{\theta_{j}}\left(t_{j} \mid x_{j}\right)\right] .
\end{aligned}
$$

Where the $j$ th observation corresponding to the time span $\left(\mathrm{t}_{0 \mathrm{j}}, \mathrm{t}_{\mathrm{j}}\right)$, with failure occurring at time $t_{j}\left(d_{j}=1\right)$ or the failure time being right censored at time $t_{j}\left(d_{j}=0\right)$. Note that in equation $4, \mathrm{f}_{\theta}()$ is the probability density function.

\subsection{Shared frailty model}

Shared frailty assumes that similar observations share frailty, even though this may vary from group to group. For instance, some individuals might be more prone to exhibit recurrences in covered unemployment than others due to unobserved reasons ${ }^{13}$.

Suppose we have a data consisting of $j$ observations and $i$ groups (incidences in covered unemployment). The index $\mathrm{i}$ denotes the group $(\mathrm{i}=1,2 . ., \mathrm{n})$ and $\mathrm{j}$ is the observation within the group $\left(\mathrm{j}=1, \ldots, \mathrm{n}_{\mathrm{i}}\right)$. The hazard rate for the $\mathrm{jth}$ individual in the ith group is

$$
\mathrm{h}_{\mathrm{ij}}\left(\mathrm{t} \mid \alpha_{\mathrm{i}}\right)=\alpha_{i} \mathrm{~h}_{\mathrm{ij}}(\mathrm{t})
$$

Where by $\mathrm{h}_{\mathrm{ij}}(\mathrm{t})$ we mean $\mathrm{h}\left(\mathrm{t} \mid \mathrm{x}_{\mathrm{ij}}\right)$, which is the individual hazard given covariates $\mathrm{x}_{\mathrm{ij}}$. For any member of the ith group, the standard hazard function is multiplied by the shared frailty term $\alpha_{i}$.

Considering the trivariate response $\left(\mathrm{t}_{0 \mathrm{ij}}, \mathrm{t}_{\mathrm{ij}}, \mathrm{d}_{\mathrm{ij}}\right)$ that indicate the start time, end time, and failure/censoring for the jth individual from the ith group, the contribution of the likelihood function for the ijth individual is (see Gutierrez, 2002) 
$L_{i j}\left(\alpha_{i}\right)=\frac{S_{i j}\left(t_{i j} \mid \alpha_{i}\right)}{S_{i j}\left(t_{0 i j} \mid \alpha_{i}\right)}\left\{h_{i j}\left(t_{i j} \mid \alpha_{i}\right)\right\}^{d_{i j}}=\left\{\frac{S_{i j}\left(t_{i j}\right)}{S_{i j}\left(t_{0 i j}\right)}\right\}^{\alpha_{i}}\left\{\alpha_{i} h_{i j}\left(t_{i j}\right)\right\}^{d_{i j}}$

Defining $D_{i}=\sum_{j=1}^{n_{i}} d_{i j}$ the likelihood function of the ith group is:

$L_{i}\left(\alpha_{i}\right)=\alpha_{i}^{D_{i}} \prod_{j=1}^{n_{i}}\left\{\frac{S_{i j}\left(t_{i j}\right)}{S_{i j}\left(t_{0 i j}\right)}\right\}^{\alpha_{i}}\left\{h_{i j}\left(t_{i j}\right)\right\}^{d_{i j}}$

Where we obtain the likelihood of the ith group integrating out $\alpha_{i}$

$$
L_{i}=\int_{0}^{\infty} L_{i}\left(\alpha_{i}\right) g\left(\alpha_{i}\right) d \alpha_{i}
$$

Finally, given the unconditional likelihood groups, we estimate the regression parameters and $\theta$ maximizing the overall log-likelihood function $L n L=\sum_{j=1}^{n_{i}} L_{n} L_{i}$

\section{Empirical results}

Here we present the estimate results obtained after applying the econometric models described in the previous section to our sample. The dependent variable is the duration of covered unemployment and as independent variables we use a set of personal characteristics (gender, age, citizenship) and job and employer attributes in the previous match (job category, types of contract, tenure, labour market experience, industry affiliation, firm size). Two forms of state dependence are accounted through the definition of a set of explanatory variables. Lagged duration dependence is the cumulative duration of all past spells of unemployment benefit and the duration of the previous employment spell ${ }^{14}$. Duration dependence is captured by using a parameter in the duration model. For the estimation of the models presented above, we assume a gamma distribution for the frailty (shared and unshared) term and a log-logistic distribution for the baseline hazard rate. The estimation results show a significant likelihood ratio test for the presence of unobserved heterogeneity term in the shared

\footnotetext{
${ }^{13}$ Sharing frailty generates dependence between the individuals who share it, whereas conditional on the frailty these individuals are independent (Gutierrez, 2002).

${ }^{14}$ In a previous version of this paper, we took account of occurrence dependence by including a variable on the type of the immediate preceding spell (employment versus unemployment benefit). We observed that past receipt of unemployment benefits induced longer spells of unemployment in the future.
} 
frailty model and we see that the frailty variance in insignificant in the unshared frailty $\operatorname{model}^{15}$.

Table 6 provides the results regarding the first incidence on unemployment benefits of individuals who find a job (or not) and do not return to the UCS in the period of observation, on the one hand; and individuals who find a job and return to the UCS (exhibiting, therefore, multiple incidences in unemployment benefits and intermediate employment periods), on the other hand. Separate estimations for expansion years (2005-2007) and recession years (2008-2010) are provided $^{16}$.

Parameters in all types of duration models are presented in terms of the "accelerated failure time" (AFT) parameterization. A negative sign on a coefficient under this parameterization implies that the duration is "shortened" by some value per unit change in the covariate, i.e. the expected time-to-failure is sooner rather than later. Consequently, it is important to note that a negative coefficient implies an increase in the hazard rate, while a positively signed coefficient implies a decrease in the hazard ${ }^{17}$. Effects related to initial conditions are measured by the cumulative duration of spells of previous benefit recipiency.

\section{[Insert Table 6]}

We first comment on estimate results of individuals who do not return to the UCS again within the period of observation. Later, we focus attention on the results of the model using information on individuals who return to the UCS and, therefore, exhibit multiples incidences in covered unemployment.

With relation to the effect of lagged benefit duration on the unemployed, there is evidence of positive lagged duration dependence in transitions from covered unemployment to employment for recipients who do not return to the UCS anymore in both periods. We find that the longer the cumulative unemployment benefit duration, the longer the current covered unemployment duration (being also longer in the boom

Nevertheless, since we are interested in reducing the initial conditions problem and the length bias, individuals who start a spell of receipt of benefits after losing a job are the only group considered.

${ }^{15} \mathrm{We}$ observe that if we choose a baseline hazard function that is monotone (Weibull) there is existence of an unobserved heterogeneity effect; however, if we choose a baseline hazard function non-monotone (log-logistic) the frailty term is not significant. In this case, the unobserved heterogeneity is attributed to the passage of the time.

${ }^{16}$ Table A.1 of the Appendix contains the means and the standard deviations for all covariates included in the models.

${ }^{17}$ In AFT models, a one unit increase in $X$ leads to a $\beta$ increase in the log survival time. An alternative interpretation is that actual survival time rises at a rate of $\beta$ or by $100 \cdot \beta$ per cent with a unit increase in $X$. One can also look at the percentage change in the survival time associated with a change in the value of some covariate, $X$, by some amount $\delta$ as follows: Percentage change $=100 \cdot(\exp (\beta * \delta)-1)$. 
than in the recession). An additional month of covered unemployment in the past increases the survival times in current covered unemployment duration by 0.3 per cent in the expansion years and around 0.8 per cent in the recession years. This result is in accord with the scarring theory: employers may use previous covered unemployment experience as a signal of workers' low productivity, which reduces their future probability of getting a job (Lockwood, 1991; Pissarides, 1992).

We have also interacted the regional unemployment rate and the lagged covered unemployment duration to investigate whether the unemployed who had covered unemployment experiences in regions with high unemployment rates are less stigmatised, as suggested by Omori (1997), or exhibit longer subsequent unemployment periods, as suggested by Pissarides (1992. Our findings (not shown) suggest that past unemployment benefit duration is longer in regions with higher unemployment rates. This result was also detected for Spain during the 1990s (see Arranz and Muro, 2004b).

Attributes of the immediately prior match seem to influence significantly unemployment exit rates. Examining the effect of previous job tenure, we find that the longer the previous job duration, the longer the expected duration of recipiency. This result can be explained because the previous job tenure is a proxy variable for benefit entitlement duration. There is substantial empirical evidence showing that job losers with longer tenure in their previous firm are more heavily hit by covered unemployment through depreciation of specific human capital (Kuhn, 2002) and that those unemployed with longer entitlement durations are the ones who exhibit lower hazard rates from unemployment in receipt of benefit (see Cebrián et al., 1995; Arranz and Muro, 2004b).

With regard to the impact of industry affiliation of previous employer, the unemployed who worked in agriculture and public administration during the boom remained longer in unemployment benefits; however, once the downswing began, workers in the construction sector make up the group who remain longer in receipt of benefits. This latter result reflects the impact of the recession in Spain, which has incorporated an idiosyncratic shock related to the end of a speculative bubble affecting the household prices and, therefore, associated with the construction sector. Therefore, the groups whose employment is more related to this sector have been the most hardly hit in terms of covered unemployment increases. Since employment in the construction sector is mainly male and its expansion has been associated with the large inflows of immigration starting in the mid-1990s, the result of the collapse of the construction has 
been a sharp and strong worsening of labour market indicators for (young) men, foreign-born people and low-skilled workers (see García-Serrano and Malo, 2013).

The contractual arrangement the individual had in the last job also affects the probability of finding a job when unemployed. The potential relationship between seasonal/temporary work and outflow form unemployment is captured in our regressions through the variable 'types of contract'. Workers with temporary contracts survive shorter in covered unemployment than workers who were holding open-ended contracts, either in expansion or in recession. Nevertheless, we should be cautions with this result since open-ended contracts are associated to longer entitlement durations and, therefore, lower hazard rates from covered unemployment.

One of the key variables with different effects on the transition from covered unemployment to a job is the employer size. While this variable did not affect the probability of exiting from covered unemployment to a job during boom years, a clear negative relationship between the firm size and the duration of unemployment benefit recipiency is observed during the trough: the larger the employer, the sooner the individuals leave compensated unemployment. This result may indicate that workers in large firms possess certain unobserved characteristics which make them more prone to come back to employment quickly. Other possibility is that large employers rest more heavily on rehirings, so unemployed workers separated temporarily from these firms exhibit greater chances of being recalled when compared with workers from small and medium-sized firms (see Alba et al., 2007; Arranz and García-Serrano, 2011), although probably this explanation applies more to the group of unemployed with multiple incidences than to this one.

The dataset we use does not include either reliable information of individual's educational attainment or data on occupation. However, it provides a variable on the job category, which is related to the required level of qualification for the job, so it may be taken as a proxy of qualifications and educational levels. The results point out that workers previously employed in white-collar high-skilled (WCHS) jobs exhibit a higher probability of finding a job and not coming back to the UCS in both periods. On the contrary, blue-collar low-skilled (BCLS) workers have less probability of finding a job. In particular, BCLS workers survive about 48 (89) per cent longer in the receipt of unemployment benefit in expansion (recession) years when compared with WCHS workers (reference category). 
Finally, personal variables such as gender and age also play a role in shaping the transitions from unemployment benefit to a job: men and younger workers survive less time in unemployment benefits than women and older workers do in both periods.

Now we turn our attention to the estimate results concerning the unemployed who experience multiple incidences in the receipt of benefits. First, we find (as previously) that the lagged cumulative benefit experience increases the current benefit duration. Nevertheless, this effect is smaller than in the case of the unemployed who find a job and do not come back to the UCS. We have also differentiated between the effect of the cumulative lagged benefit duration of previous periods and the lagged duration between unemployment benefit periods, in order to distinguish between short-run and long-run effects of previous unemployment benefit experience. The results (not shown) suggest that the longer the lagged benefit period, the longer the current benefit duration, being this effect bigger than with the cumulative lagged duration variable.

The effects of some variables (job category, firm size, regional conditions and age) are rather similar to the ones obtained previously. For instance, in the case of the impact of age, we find that younger workers are more likely to exit unemployment benefits sooner than older workers. It is a fact that they are more willing to move from jobs for improving their job match and eventually settling in a more stable career path. Nevertheless, it is also true that temporary employment fall disproportionally on young workers, so they are more prone to enter unemployment involuntarily and move repeatedly between employment and unemployment. With regards to the impact of the regional economic conditions, the probability of finding a job in regions with unemployment rates under the average is significantly higher than in regions with unemployment rates over the average in all estimations, although this effect is slightly smaller during the recession period.

On the other hand, the impacts of gender, citizenship and industry change considerably. While women who find a job and do not return to the UCS remain longer in unemployment benefit than their male counterparts, male (and non-Spanish) workers are the groups who exhibit less probability of finding a job among the ones who experience multiples incidences in unemployment benefits. Moreover, when compared with individuals who worked in the construction sector, workers from agriculture, public administration and education exhibit are less likely to move to employment. On the contrary, workers from the health sector show a higher probability of transitions between unemployment benefit and unstable employment: they survive about 87 per 
cent shorter time in unemployment benefit than the ones from the reference group. This finding agrees with previous results concerning the extension of rehirings and the linking of successive short contracts with periods of unemployment benefit in that sector (Arranz and García-Serrano, 2011).

Finally, Figure 1 captures the estimated current duration dependence distinguishing between the individuals who find a job and return to the UCS and the ones who find a job and do not return (at first incidence). First, there is positive duration dependence up to a maximum between 0 and 3 months and negative duration dependence thereafter. The negative duration dependence is especially strong for the individuals who do not return to the UCS. The large increase in the intensity during the first three months can be explained by the fact that the high-skilled generally find a job during the first months of unemployment benefit. The negative duration dependence may be due to loss of human capital or stigmatization effects.

Second, the estimated hazard rates of recipients who find a job and return to the UCS are higher than the ones corresponding to the unemployed who find a job and do not return to the UCS (in both periods). Third, this latter group remained in unemployment benefit shorter during the boom years than during the trough years; however, in the case of the former, there are not differences between periods in the estimated hazard rate.

\section{[Insert Figure 1]}

\section{Conclusions}

The objective of this paper has been to investigate the duration and recurrence in the receipt of unemployment benefits in Spain across the period 2005-2010. We have focused attention on examining, on the one hand, whether unemployment benefit may be characterised by the existence of a large group of workers with long recipiency durations and other, less numerous group incurring in more recurrence in compensated unemployment and shorter durations, and, on the other hand, which are factors associated with the duration and recurrence in unemployment benefits. In order to carry out this analysis, we have made use of administrative data from the MCVL defining an observation window of equal length for two periods, one of expansion years (20052007 ) and other of the recession years (2008-2010), which allows one to analyse the impact of changing economic conditions on unemployment benefit duration and 
recurrence. This is the first paper that addresses the study of recurrence in UCS using the referred data and methodology for $\operatorname{Spain}^{18}$.

Regarding the first issue, our findings suggest the existence of (at least) three groups of unemployed:

- The first one (55\% and 64\% of the individuals accessing the UCS in 2005 and in 2008, respectively, after the loss of a job) is comprised of workers who enter and exit the UCS with relatively short unemployment benefit durations (their durations were 109 days in 2005-2007 and 122 in 2008-2010).

- The second one (37\% in 2005 and $23 \%$ in 2008) is made up of individuals who exhibit only one but long experience in the UCS, returning to employment in a relatively longer period of time (189 days in 2005-2007 and 217 days in 20082010).

- And the third one (7.8\% in 2005 and $12.8 \%$ in 2008) consists of workers who spend a lot of time out of employment (578 days in 2005-2007 and 590 days in 2008-2010) and end up either out of the labour force or still receiving benefits at the end of a period of three years.

We find that the recurrence and duration in unemployment benefits are relatively high and have increased during the recession period compared to the boom years.

As for the second question, we find that recurrent and duration in unemployment benefits is not only affected by seasonal effects or demand factors but also by personal or job characteristics and by the previous unemployment experience in benefits. In particular, we find evidence that the previous unemployment benefit increase the current unemployment benefit duration, being this effect also longer in the boom than in the recession, and higher in the individuals with multiples incidences in UCS than those with only one incidence. This result is consistent with the scarring theory (Lockwood, 1991; Pissarides, 1992), where employers use previous unemployment experience as a signal of workers' low productivity or human capital decay.

The coefficients obtained by variables related to personal characteristics of workers who do not return UCS more indicate that survive more time in unemployment benefits women, older people and blue collar low skilled (who are presumably in possession of lower specific human capital). Concerning job characteristics, workers

\footnotetext{
${ }_{18}$ As we mentioned above, there are few studies that analyse recurrence in unemployment benefits: Cebrian et al. (1995) for the period 1984-1991 and Arranz and Muro (2004b) for the period 1987-1995.
} 
who held an open-ended contract; were employed in a small firm and their job was in the construction sector survive more time in unemployment benefits.

In contrast, for the workers with multiple incidences in unemployment benefits whilst some variables as job category, firm size and age are rather similar to the ones mentioned for the unemployed with one incidence. Others as the impact of gender, citizenship and industry change considerably. Thus, men, non-Spanish and workers from the public administration, education and agriculture are the group of unemployed who remain longer time in unemployment benefits within the group of unemployed with multiples incidences in UCS. On the contrary, workers from the health sector exhibit higher probability of exiting from UCS to unstable employment.

Another important result is that the duration dependence differs in magnitude (not much in shape) and over business cycle on the collective of unemployed considered. Whist the duration dependence is positive during the first months (up to three months) and negative duration dependence thereafter in both groups (especially negative for the unemployed with multiple incidences); the estimated hazard rates of the unemployed with multiple incidences are higher than those with only one incidence. There are not effects of the business cycle over the estimated hazard rates in the case of the former, but for the latter group the estimated hazard rate is higher in the boom years than in the recession years.

In summary, our results should contribute to an understanding of duration and recurrent unemployment benefit and help to implement adequate policy measures. Our findings indicate that there seems to be a sort of segmentation in the Spanish labour market into individuals with longer unemployment benefit duration and longer jobs, on the one hand, and individuals with frequently transitions between unemployment benefits and unstable employment with multiples incidences in UCS, on the other hand. Government could design policy measures (e.g. promoting education or training) that help specific collectives (women, older workers, non-manual low skilled) to reduce long-term unemployment. A labour market reform on the UCS that include experience rating system is necessary to limit the pervasive use of fixed-term contracts and repeated use of the unemployment benefits. We have to avoid that unemployment benefits will artificially subsidize the regular use of temporary jobs. 


\section{References}

Alba-Ramírez, A. (1998). "Re-employment Probabilities of Young Workers in Spain" Investigaciones Económicas, 22(2), 201-224.

Alba-Ramírez, A., Arranz, J.M. and Muñoz-Bullón, F. (2007), "Exits from unemployment: recall or new job?", Labour Economics, 14, 788-810.

Arulampalam, W.; Booth, A.L. and Taylor, M.P. (2000) "Unemployment persistence", Oxford Economic Papers, 52, 24-50.

Arranz, J.M. y Muro, J. (2004a),“An extra time duration model with application to unemployment duration under benefits in Spain", Hacienda Pública Española, 168(4), 133-156.

Arranz, J.M. and Muro, J. (2004b), "Recurrent unemployment and welfare system", International Review of Applied Economics, 18(4), 423-441.

Arranz, J.M., Muñoz-Bullón, F. and Muro, J. (2009), "Do unemployment benefit legislative changes affect job finding?", Moneda y Crédito, 228, 7-44.

Arranz, J.M., García-Serrano, C. and Hernanz, V. (2012), "How do we pursue labormetrics? An application using the MCVL", Alcamentos, $\mathrm{n}^{\circ}$ 1201, Universidad de Alcalá.

Arranz, J.M. and García-Serrano, C. (2011), "Tie me up, tie me down! The interplay of the Unemployment Compensation System, fixed-term contracts and rehirings", Documentos de Trabajo, FUNCAS, nº 586, Madrid.

Atkinson, A.B. and Mickelwright, J. (1991), "Unemployment Compensation and Labor Market Transitions: A Critical Review", Journal of Economic Literature, 29(4), 1679-1727.

Blanchard, O. and Summers, L. (1986), "Hysteresis and the European Unemployment Problem", in Fischer, S. (Ed.), NBER Macroeconomic Annual, MIT Press, Cambridge, Mass.

Bover, O. Arellano, M. and Bentolila, S. (2002), "Unemployment Duration, benefit duration, and the business cycle", The Economic Journal, 112, 1-43.

Cebrián, I., García-Serrano, C., Muro, J., Toharia, L. and Villagómez, E. (1995), "Prestaciones por desempleo, duración y recurrencia del paro", 155-193, en J.J. Dolado y J.F. Jimeno (comps.), Estudios sobre el funcionamiento del mercado de trabajo español, Colección Estudios, 13, FEDEA, Madrid.

Clark, K.B. and Summers, L.H. (1979), "Labor Market Dynamics and Unemployment: a Reconsideration”, Brookings Papers on Economic Activity, 1, 13-72. 
Cleves, M.A., Gould, W.W. and Gutierrez, R.G. 2004), An introduction to survival analysis using Stata, Revised edition, , Stata Press, Texas (USA).

Flaig, G. Licht, G. \& Steiner, V. (1993), "Testing for state dependence effects in a dynamic model of male unemployment behaviour", in: H Bunzel, P. Jensen and N. Westergard-Nielsen (eds), Panel Data and Labour Market Dynamics (North Holland, Amsterdam).

García-Serrano, C. and Malo, M.A. (2013), "Employment and the Quality of Jobs. Country case studies on labour market segmentation: Spain", Report for the OIT.

Gregg, P. (2001), "The impact of youth unemployment on adult unemployment in the NCDS", The Economic Journal, 111, 626-653.

Gutierrez, R.G., (2002), "Parametric frailty and shared frailty survival models", The Stata Journal, 2(1), 22-44.

Heckman, J. and Borjas G. I. (1980), "Does unemployment cause future unemployment? Definitions, questions and answers for a continuous time model of heterogeneity and state dependence", Economica, 47, 247-283.

Jenkins, S.P. and García-Serrano, C. (2004), "The relationship between unemployment benefits and re-employment probabilities: evidence from Spain", Oxford Bulletin of Economics and Statistics, 66, 239-260.

Jovanovic, B. (1979a). "Job Matching and the Theory of Turnover", Journal of Political Economy, 87, 972-990.

Kuhn, P.J. (ed.) (2002), Losing Work, Moving on: International Perspectives on Worker Displacement, Kalamazoo: W.E. Upjohn Institute for Employment Research.

Lockwood, B. (1991), "Information externalities in the labour market and the duration of unemployment", Review of Economic Studies, July, 733-753.

Lynch, L. M. (1989), "The Youth Labor Market in the Eighties: Determinants of Reemployment Probabilities for Young Men and Women", Review of Economics and Statistics, February: 37-45.

Mortensen, D.T. (1977), "Unemployment insurance and job search decisions", Industrial and Labour Relations Review, 30, 505-517.

Mortensen, D. (1988), "Job search and labour market analysis", in Ashenfelter, O. and Layard, R. (eds.), Handbook of Labor Economics, II, North Holland, Amsterdam, 849-919.

Muthleisen, M. and Zimmerman K.F. (1994), “A panel analysis of job changes and unemployment”, European Economic Review, 38, 793-801. 
Pissarides, C. (1992), "Loss of Skills during Unemployment and the Persistence of Employment Shocks", Quarterly Journal of Economics ,107, 1371-1391.

Omori, Y. (1997), "Stigma effects of nonemployment", Economic Inquiry, XXXV, April, 394-416.

Phelps, E.S. (1982), Inflation policy and unemployment theory: the cost-benefit approach to monetary planning, W.W. Norton, New York.

Piore, M. J. (1971). 'The Dual Labour Market: Theory and Implications', in D. M. Gordon (ed.), Problems in Political Economy: an Urban Perspective, Lexington, MA, D.C. Heath.

Piore, M.J. (1985), "Notes for a theory of labor market stratification”, in Edwards, R.C., Reich. M. and Gordon, D.M. (eds.), Labour Market Segmentation, Lexington Mass (Health), 125-150.

Pissarides, C., (1985), "Job search and the functioning of labour markets", in Carline, D. et al. (eds.), Surveys in Economics: Labour Economics, Longmans, LondonNew York, 159-185.

Roed, K., Oddbjorn, R and Goldstein, H., (1999), "Does unemployment cause unemployment? Micro evidence from Norway", Applied Economics, 31, 12071218.

Steiner, Vl, (1989), "Causes of recurrent unemployment- An empirical analysis", Empirica, 16 (1), 53-65.

Steiner, V., (1990), "Long-term unemployment, heterogeneity, and state dependence", Empirica, 17,41-59.

Steiner, V., (1989), "Causes of recurrent unemployment-An empirical analysis", Empirica, 16, 53-65.

Therneau, T.M. (1997), "Extending the Cox Model”, Proceedings of the First Seattle Symposium in Biostatistics, New York: Springer-Verlag.

Trivedi, P.K. and Alexander J.N. (1989), "Reemployment Probability and Multiple Unemployment Spells: A Partial Likelihood Approach", Journal of Business and Economic Statistics, July, 395-401.

Winter-Ebmer, R. and Zweimüller, J. (1992), "Do they come back again? Job search, labour market segmentation and state dependence as explanations of repeat unemployment", Empirical Economics, 17, 273-292.

Vishwanath, T. (1989), "Job Search, Stigma Effect, and Scape Rate from Unemployment", Journal of Labour Economics, 4, 487-502. 
Table 1. Number of spells of unemployment benefits starting each year, by origin. MCVL, 2004-2010.

\begin{tabular}{|c|c|c|c|c|c|c|c|c|}
\hline & & 2004 & 2005 & 2006 & 2007 & 2008 & 2009 & 2010 \\
\hline \multirow[t]{3}{*}{ Missing value } & & & & & & & & \\
\hline & Cases & 5,900 & 4,125 & 4,250 & 17,175 & 15,100 & 13,825 & 17,900 \\
\hline & $\%$ & 0.17 & 0.11 & 0.12 & 0.4 & 0.26 & 0.15 & 0.18 \\
\hline \multirow[t]{2}{*}{$\begin{array}{c}\text { Self- } \\
\text { employment }\end{array}$} & Cases & 22,250 & 22,475 & 23,175 & 30,850 & 38,325 & 50,725 & 52,200 \\
\hline & $\%$ & 0.63 & 0.62 & 0.63 & 0.72 & 0.66 & 0.54 & 0.53 \\
\hline \multirow[t]{3}{*}{ No mention } & & & & & & & & \\
\hline & Cases & 13,350 & 10,375 & 9,525 & 16,125 & 13,650 & 15,650 & 15,625 \\
\hline & $\%$ & 0.38 & 0.29 & 0.26 & 0.38 & 0.24 & 0.17 & 0.16 \\
\hline \multirow[t]{2}{*}{$\begin{array}{l}\text { Open ended } \\
\text { contract }\end{array}$} & Cases & 534,375 & 552,425 & 578,400 & 673,375 & 993,875 & $1,336,550$ & $1,027,625$ \\
\hline & $\%$ & 15.11 & 15.3 & 15.66 & 15.82 & 17.21 & 14.29 & 10.45 \\
\hline \multirow[t]{2}{*}{$\begin{array}{c}\text { Temporary per } \\
\text { task }\end{array}$} & Cases & 865,650 & 885,175 & 928,400 & $1,084,950$ & $1,593,400$ & $1,647,475$ & $1,641,075$ \\
\hline & $\%$ & 24.47 & 24.51 & 25.13 & 25.49 & 27.59 & 17.61 & 16.68 \\
\hline \multirow[t]{3}{*}{ Casual contract } & & & & & & & & \\
\hline & Cases & 715,500 & 722,000 & 747,375 & 811,125 & $1,069,650$ & $1,155,575$ & $1,171,750$ \\
\hline & $\%$ & 20.23 & 20 & 20.23 & 19.06 & 18.52 & 12.35 & 11.91 \\
\hline \multirow[t]{2}{*}{$\begin{array}{l}\text { Other fixed- } \\
\text { term contract }\end{array}$} & Cases & 330,275 & 322,600 & 318,150 & 354,400 & 438,900 & 554,375 & 615,725 \\
\hline & $\%$ & 9.34 & 8.93 & 8.61 & 8.33 & 7.6 & 5.93 & 6.26 \\
\hline \multirow[t]{2}{*}{$\begin{array}{c}\text { Agricultural } \\
\text { jobs }\end{array}$} & Cases & 285,325 & 280,375 & 281,925 & 286,475 & 330,825 & 403,100 & 455,375 \\
\hline & $\%$ & 8.07 & 7.76 & 7.63 & 6.73 & 5.73 & 4.31 & 4.63 \\
\hline \multirow[t]{3}{*}{ Domestic Work } & & & & & & & & \\
\hline & Cases & 600 & 525 & 975 & 3,775 & 4,175 & 5,875 & 6,875 \\
\hline & $\%$ & 0.02 & 0.01 & 0.03 & 0.09 & 0.07 & 0.06 & 0.07 \\
\hline \multirow[t]{2}{*}{$\begin{array}{c}\text { UI (Job } \\
\text { extinción) }\end{array}$} & Cases & 387,100 & 412,525 & 428,300 & 531,600 & 749,700 & $1,324,625$ & $1,387,875$ \\
\hline & $\%$ & 10.94 & 11.42 & 11.59 & 12.49 & 12.98 & 14.16 & 14.11 \\
\hline \multirow[t]{2}{*}{$\begin{array}{c}\text { UI (Job } \\
\text { suspensión) }\end{array}$} & Cases & 41,050 & 61,725 & 42,075 & 94,625 & 96,200 & $2,036,750$ & $2,063,200$ \\
\hline & $\%$ & 1.16 & 1.71 & 1.14 & 2.22 & 1.67 & 21.77 & 20.98 \\
\hline \multirow[t]{3}{*}{$\begin{array}{l}\text { UA (+52 years } \\
\text { or temporary } \\
\text { per task) }\end{array}$} & & & & & & & & \\
\hline & Cases & 32,900 & 34,000 & 32,325 & 35,525 & 33,850 & 63,350 & 85,625 \\
\hline & $\%$ & 0.93 & 0.94 & 0.87 & 0.83 & 0.59 & 0.68 & 0.87 \\
\hline \multirow[t]{3}{*}{$\begin{array}{c}\text { UA (job } \\
\text { extinction and } \\
\text { suspension) }\end{array}$} & & & & & & & & \\
\hline & Cases & 303,025 & 302,475 & 299,600 & 316,250 & 396,700 & 747,225 & $1,294,875$ \\
\hline & $\%$ & 8.57 & 8.38 & 8.11 & 7.43 & 6.87 & 7.99 & 13.17 \\
\hline $\begin{array}{l}\text { Weighted } \\
\text { sample }\end{array}$ & $\begin{array}{c}\text { Cases } \\
\%\end{array}$ & $\begin{array}{c}3,537,300 \\
100\end{array}$ & $\begin{array}{c}3,610,800 \\
100\end{array}$ & $\begin{array}{c}3,694,475 \\
100\end{array}$ & $\begin{array}{c}4,256,250 \\
100\end{array}$ & $\begin{array}{c}5,774,350 \\
100\end{array}$ & $\begin{array}{c}9,355,100 \\
100\end{array}$ & $\begin{array}{c}9,835,725 \\
100\end{array}$ \\
\hline
\end{tabular}

Note: Own elaboration with the MCVL. "UI" means unemployment insurance and "UA" unemployment assistance. 
Table 2. Mean and distribution of duration of unemployment benefits starting in 2005 or 2008 (spells and individuals). MCVL, 2005-2010.

\begin{tabular}{|c|c|c|c|c|}
\hline & \multicolumn{2}{|c|}{$\begin{array}{c}\text { Starts in } 2005 \\
(2005-2007 \text { period })\end{array}$} & \multicolumn{2}{|c|}{$\begin{array}{c}\text { Starts in } 2008 \\
(2008-2010 \text { period })\end{array}$} \\
\hline & Spells & Individuals & Spells & Individuals \\
\hline \multicolumn{5}{|l|}{ 1st incidence } \\
\hline Mean duration & 125 & 201 & 141 & 250 \\
\hline \multicolumn{5}{|l|}{ Percentile $(\%)$} \\
\hline 1 & 1 & 4 & 1 & 4 \\
\hline 5 & 4 & 13 & 2 & 14 \\
\hline 10 & 9 & 22 & 7 & 25 \\
\hline 25 & 30 & 52 & 30 & 61 \\
\hline 50 & 87 & 120 & 96 & 143 \\
\hline 75 & 181 & 240 & 183 & 351 \\
\hline 90 & 282 & 534 & 334 & 716 \\
\hline 95 & 394 & 729 & 485 & 816 \\
\hline 99 & 729 & 1.096 & 729 & 990 \\
\hline \multicolumn{5}{|l|}{ All incidences } \\
\hline Average number of spells & - & $2,6(2)$ & - & $3,4(3)$ \\
\hline Average number of incidences & - & $2,1(1)$ & - & $2,4(2)$ \\
\hline Average incidence duration & - & $141(78)$ & - & $163(85)$ \\
\hline $\begin{array}{l}\text { Accumulated average duration } \\
\text { of incidences }\end{array}$ & - & $296(210)$ & - & $392(335)$ \\
\hline Observations(weighted) & $3,111,075$ & $2,217,075$ & $5,087,375$ & $3,446,275$ \\
\hline
\end{tabular}

Note: See Table 1. 
Table 3. Number of incidences in the UCS of individuals. MCVL, 2005-2010.

\begin{tabular}{|c|c|c|c|c|c|c|}
\hline & \multicolumn{3}{|c|}{ Years 2005-2007 } & \multicolumn{3}{|c|}{ Years 2008-2010 } \\
\hline $\begin{array}{l}\text { Number of } \\
\text { incidences }\end{array}$ & Cases & $\%$ & $\begin{array}{c}\% \\
\text { accumulated }\end{array}$ & Cases & $\%$ & $\%$ accumulated \\
\hline 1 & 9,398 & 44.9 & 44,9 & 10.447 & 36.2 & 36.2 \\
\hline 2 & 5,056 & 24.1 & 69,0 & 6.842 & 23.7 & 59.9 \\
\hline 3 & 2,753 & 13.1 & 82,1 & 4.464 & 15.5 & 75.4 \\
\hline 4 & 1,542 & 7.4 & 89,5 & 2.774 & 9.6 & 85.0 \\
\hline 5 & 828 & 4.0 & 93,5 & 1.521 & 5.3 & 90.3 \\
\hline 6 & 439 & 2.1 & 95,5 & 897 & 3.1 & 93.4 \\
\hline 7 & 246 & 1.2 & 96,7 & 543 & 1.9 & 95.3 \\
\hline 8 & 145 & 0.7 & 97,4 & 333 & 1.2 & 96.4 \\
\hline 9 & 105 & 0.5 & 97,9 & 202 & 0.7 & 97.1 \\
\hline 10 & 69 & 0.3 & 98,2 & 132 & 0.5 & 97.6 \\
\hline+10 & 369 & 1.8 & 100 & 697 & 2.4 & 100.0 \\
\hline Sample & \multicolumn{3}{|c|}{20,950} & \multicolumn{3}{|c|}{28,852} \\
\hline Weighted & \multicolumn{3}{|c|}{523,750} & \multicolumn{3}{|c|}{721,300} \\
\hline
\end{tabular}

Source: See Table 1.

Table 4. Unemployment benefits distribution (in days) by order of incidences. MCVL, 2005-2010.

\begin{tabular}{|c|c|c|c|c|c|c|}
\hline & \multicolumn{3}{|c|}{ Years 2005-2007 } & \multicolumn{3}{|c|}{ Years 2008-2010 } \\
\hline & \multicolumn{3}{|c|}{ Incidences } & \multicolumn{3}{|c|}{ Incidences } \\
\hline Distribution & $1^{\text {st }}$ & 2nd & 3rd & 1st & 2nd & 3rd \\
\hline Percentile (\%) & & & & & & \\
\hline 1 & 2 & 1 & 1 & 3 & 2 & 1 \\
\hline 5 & 9 & 6 & 4 & 10 & 7 & 5 \\
\hline 10 & 16 & 11 & 9 & 18 & 13 & 10 \\
\hline 25 & 40 & 26 & 20 & 42 & 32 & 26 \\
\hline 50 & 103 & 67 & 52 & 110 & 89 & 69 \\
\hline 75 & 192 & 134 & 120 & 239.5 & 194 & 158 \\
\hline 90 & 446.5 & 240 & 198 & 609 & 394 & 294 \\
\hline 95 & 668 & 342 & 267 & 823 & 581 & 410 \\
\hline 99 & 1067 & 684 & 498 & 1045 & 841 & 718 \\
\hline Sample & 20,950 & 11,552 & 6,496 & 28,852 & 18,405 & 11,563 \\
\hline Weighted & 523,750 & 288,800 & 162,400 & 721,300 & 460,125 & 289,075 \\
\hline $\begin{array}{l}\text { Mean } \\
(S . E) \\
\end{array}$ & $\begin{array}{c}176 \\
(230) \\
\end{array}$ & $\begin{array}{c}109 \\
(148) \\
\end{array}$ & $\begin{array}{c}87 \\
(116) \\
\end{array}$ & $\begin{array}{c}204 \\
(253) \\
\end{array}$ & $\begin{array}{c}155 \\
(186) \\
\end{array}$ & $\begin{array}{c}120 \\
(146) \\
\end{array}$ \\
\hline
\end{tabular}

Note: See Table 1. 
Table 5. Unemployment benefits distribution (in days) of first incidence of individuals who either return or do not to the UCS. MCVL, 2005-2010.

\begin{tabular}{|c|c|c|c|c|c|c|c|c|}
\hline & \multicolumn{4}{|c|}{ Years 2005-2007 } & \multicolumn{4}{|c|}{ Years 2008-2010 } \\
\hline & \multicolumn{3}{|c|}{$\begin{array}{l}\text { Do not return UCS } \\
\text { (1st incidence) }\end{array}$} & \multirow{2}{*}{$\begin{array}{c}\text { Return } \\
\text { UCS (+1 } \\
\text { incid.) } \\
\text { All }\end{array}$} & \multicolumn{3}{|c|}{$\begin{array}{l}\text { Do not return UCS } \\
\text { (1st incidence) }\end{array}$} & \multirow{2}{*}{$\begin{array}{c}\text { Return } \\
\text { UCS (+1 } \\
\text { incid.) }\end{array}$} \\
\hline & All & Find a job & $\begin{array}{c}\text { Do not } \\
\text { find a job }\end{array}$ & & All & $\begin{array}{c}\text { Find a } \\
\text { job }\end{array}$ & $\begin{array}{c}\text { Do not } \\
\text { find a job }\end{array}$ & \\
\hline $\begin{array}{l}\text { Mean } \\
(\text { S.E. }) \\
\text { Percentile (\%) }\end{array}$ & $257(296)$ & $\begin{array}{c}189 \\
(195)\end{array}$ & $578(445)$ & $109(123)$ & $349(327)$ & $217(222)$ & $590(351)$ & $122(143)$ \\
\hline 1 & 5 & 5 & 6 & 2 & 5 & 5 & 7 & 2 \\
\hline 5 & 16 & 15 & 54 & 7 & 18 & 14 & 90 & 8 \\
\hline 10 & 26 & 24 & 120 & 12 & 35 & 26 & 121 & 14 \\
\hline 25 & 69 & 58 & 184 & 30 & 101 & 67 & 243 & 32 \\
\hline 50 & 141 & 120 & 546 & 72 & 186 & 124 & 653 & 77 \\
\hline 75 & 336 & 242 & 730 & 138 & 599 & 270 & 940 & 149 \\
\hline 90 & 669 & 467 & 1.095 & 243 & 918 & 581 & 1.031 & 282 \\
\hline 95 & 749 & 644 & 1.379 & 364 & 1.017 & 729 & 1.057 & 427 \\
\hline 99 & 1,354 & 769 & 2,106 & 638 & 1,070 & 939 & 1,093 & 724 \\
\hline Sample & 9,398 & 7,764 & 1,634 & 11,552 & 10,447 & 6,759 & 3,688 & 18,405 \\
\hline Weighted & 234,950 & 194,100 & 40,850 & 288,800 & 261,175 & 168,975 & 92,200 & 460,125 \\
\hline
\end{tabular}

Note: See Table 1. 
Table 6. Estimate results of the duration log-logistic model. Individuals who (1) find a job and do not return to the UCS and (2) find a job and have multiples incidences in the UCS. MCVL, 2005-2010.

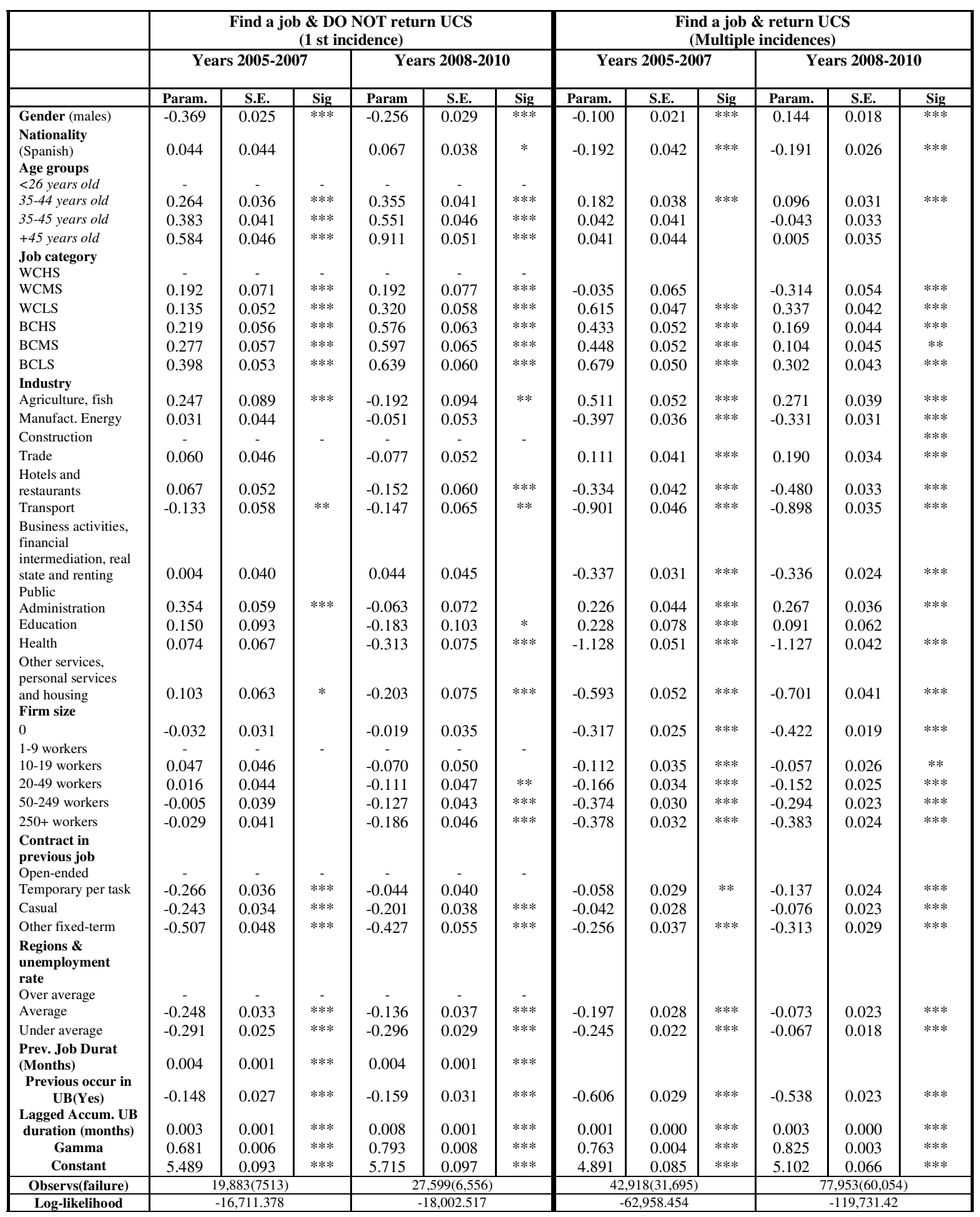


Figure 1. Estimated hazard rates from Table 6. MCVL, 2005-2010.

\section{Estimated hazard rates 2005-2007 2008-2010}
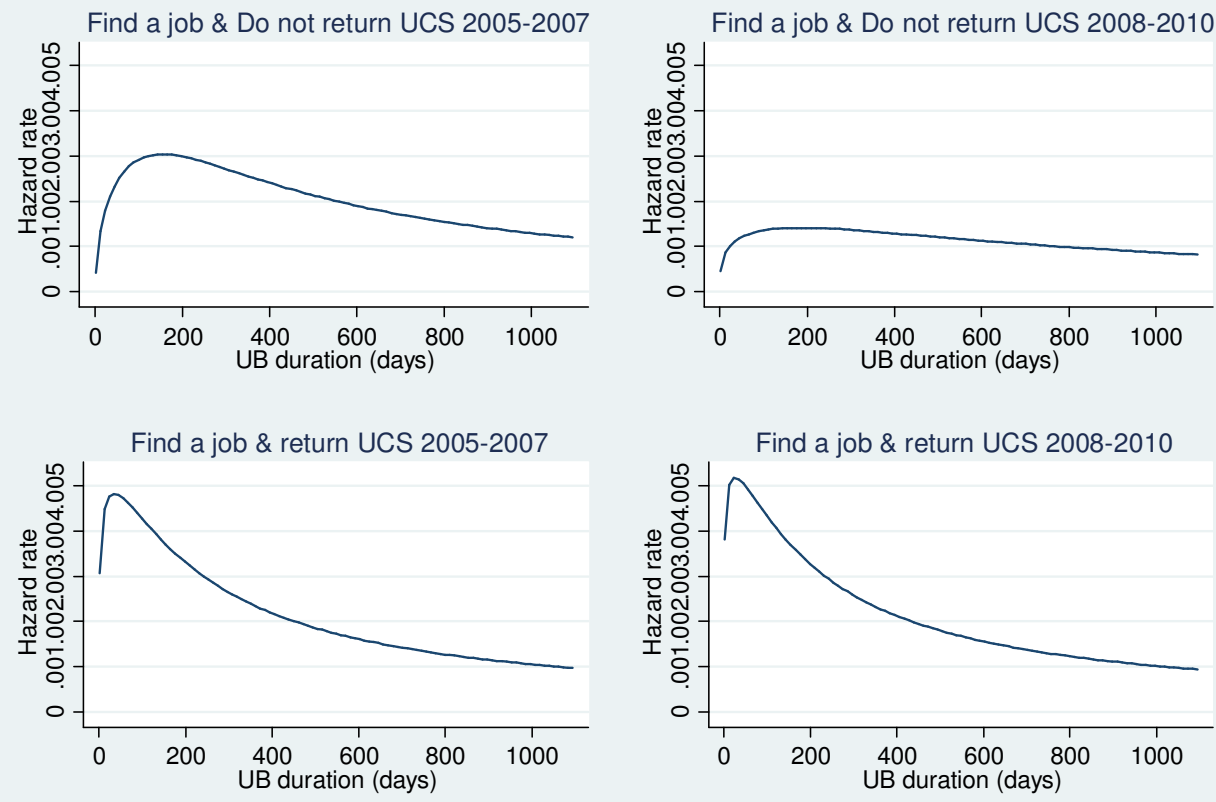


\section{APPENDIX}

Table A.1. Descriptive statistics (mean) of first incidence on unemployment benefit of individuals who either return or do not return to the UCS. MCVL, 2005-2010.

\begin{tabular}{|c|c|c|c|c|c|c|}
\hline & \multicolumn{3}{|c|}{ Years 2005-2007 } & \multicolumn{3}{|c|}{ Years 2008-2010 } \\
\hline & \multicolumn{2}{|c|}{$\begin{array}{l}\text { Do not return UCS } \\
\text { (1st incidence) }\end{array}$} & \multirow{2}{*}{$\begin{array}{c}\text { Return } \\
\text { UCS (+1 } \\
\text { incid.) } \\
\begin{array}{c}\text { Find } a \\
\text { job }\end{array}\end{array}$} & \multicolumn{2}{|c|}{$\begin{array}{l}\text { Do not return UCS } \\
\text { (1st incidence) }\end{array}$} & \multirow{2}{*}{$\begin{array}{c}\text { Return } \\
\text { UCS (+1 } \\
\text { incid.) } \\
\text { Vuelven } \\
\text { al SPD }\end{array}$} \\
\hline & $\begin{array}{l}\text { Find } a \\
\text { job }\end{array}$ & $\begin{array}{c}\text { Do not } \\
\text { find a job } \\
\end{array}$ & & $\begin{array}{c}\text { Do not } \\
\text { find } a \text { job } \\
\end{array}$ & $\begin{array}{l}\text { Find } a \\
\text { job }\end{array}$ & \\
\hline \multicolumn{7}{|l|}{ Gender } \\
\hline Males & 0.553 & 0.347 & 0.520 & 0.539 & 0.508 & 0.578 \\
\hline Females & 0.447 & 0.653 & 0.480 & 0.461 & 0.492 & 0.422 \\
\hline \multicolumn{7}{|l|}{ Nationality } \\
\hline Spanish & 0.928 & 0.918 & 0.929 & 0.843 & 0.814 & 0.846 \\
\hline \multicolumn{7}{|l|}{ Age groups } \\
\hline Less than 30 years & 0.365 & 0.182 & 0.288 & 0.347 & 0.206 & 0.269 \\
\hline$>30 \& 45$ years & 0.475 & 0.446 & 0.494 & 0.485 & 0.454 & 0.498 \\
\hline$>45$ years & 0.160 & 0.371 & 0.219 & 0.169 & 0.340 & 0.233 \\
\hline \multicolumn{7}{|l|}{ Job category } \\
\hline WCHS & 0.069 & 0.053 & 0.048 & 0.072 & 0.031 & 0.041 \\
\hline WCMS & 0.045 & 0.040 & 0.034 & 0.055 & 0.039 & 0.033 \\
\hline WCLS & 0.277 & 0.277 & 0.209 & 0.281 & 0.254 & 0.197 \\
\hline BCHS & 0.204 & 0.165 & 0.215 & 0.205 & 0.233 & 0.275 \\
\hline BCMS & 0.157 & 0.165 & 0.159 & 0.140 & 0.154 & 0.146 \\
\hline BCLS & 0.248 & 0.300 & 0.335 & 0.246 & 0.289 & 0.309 \\
\hline \multicolumn{7}{|l|}{ Industry } \\
\hline Agriculture and fish & 0.017 & 0.023 & 0.030 & 0.024 & 0.014 & 0.033 \\
\hline Manufact. and energy & 0.162 & 0.166 & 0.151 & 0.128 & 0.137 & 0.113 \\
\hline Construction & 0.127 & 0.084 & 0.124 & 0.111 & 0.152 & 0.130 \\
\hline Trade & 0.169 & 0.207 & 0.128 & 0.175 & 0.183 & 0.110 \\
\hline Hotels and restaurants & 0.085 & 0.094 & 0.094 & 0.084 & 0.088 & 0.089 \\
\hline Transport & 0.065 & 0.040 & 0.049 & 0.067 & 0.048 & 0.050 \\
\hline \multicolumn{7}{|l|}{$\begin{array}{l}\text { Business activities, financial } \\
\text { intermediation, real state }\end{array}$} \\
\hline $\begin{array}{l}\text { intermediation, real state } \\
\text { and renting }\end{array}$ & 0.213 & 0.186 & 0.216 & 0.247 & 0.253 & 0.305 \\
\hline Public Administration & 0.054 & 0.085 & 0.077 & 0.048 & 0.041 & 0.060 \\
\hline Education & 0.017 & 0.017 & 0.016 & 0.020 & 0.013 & 0.017 \\
\hline Health & 0.047 & 0.043 & 0.077 & 0.055 & 0.032 & 0.061 \\
\hline \multicolumn{7}{|l|}{ Other services, personal } \\
\hline services and housing & 0.044 & 0.056 & 0.037 & 0.041 & 0.039 & 0.031 \\
\hline \multicolumn{7}{|l|}{ Firm size } \\
\hline 0 & 0.382 & 0.323 & 0.340 & 0.314 & 0.346 & 0.330 \\
\hline $1-9$ workers & 0.185 & 0.218 & 0.156 & 0.207 & 0.242 & 0.190 \\
\hline 10-19 workers & 0.076 & 0.089 & 0.079 & 0.087 & 0.084 & 0.083 \\
\hline 20-49 workers & 0.089 & 0.116 & 0.106 & 0.104 & 0.098 & 0.102 \\
\hline 50-249 workers & 0.136 & 0.134 & 0.154 & 0.143 & 0.124 & 0.147 \\
\hline $250+$ workers & 0.132 & 0.120 & 0.166 & 0.144 & 0.107 & 0.149 \\
\hline \multicolumn{7}{|l|}{ Contract in previous job } \\
\hline Open-ended & 0.245 & 0.384 & 0.164 & 0.286 & 0.347 & 0.177 \\
\hline Temporary per task & 0.325 & 0.248 & 0.369 & 0.295 & 0.334 & 0.409 \\
\hline Casual & 0.317 & 0.274 & 0.314 & 0.308 & 0.267 & 0.276 \\
\hline Other fixed-term & 0.113 & 0.094 & 0.154 & 0.111 & 0.052 & 0.137 \\
\hline \multicolumn{7}{|l|}{ Previous job duration } \\
\hline$<6$ months & 0.478 & 0.378 & 0.655 & 0.490 & 0.436 & 0.638 \\
\hline$\geq 6$ months $\&<1$ year & 0.194 & 0.161 & 0.176 & 0.178 & 0.170 & 0.180 \\
\hline$\geq 1$ year $\mathrm{y}<3$ years & 0.242 & 0.252 & 0.130 & 0.234 & 0.236 & 0.140 \\
\hline$\geq 3$ years & 0.087 & 0.208 & 0.039 & 0.098 & 0.157 & 0.042 \\
\hline Labour experience & & & & & & \\
\hline
\end{tabular}




\begin{tabular}{|l|c|c|c|c|c|c|}
\hline$\leq 2$ & 0.162 & 0.167 & 0.122 & 0.150 & 0.151 & 0.103 \\
$>2 \& \leq 3$ years & 0.129 & 0.103 & 0.114 & 0.136 & 0.126 & 0.112 \\
$>3 \& \leq 6$ years & 0.316 & 0.257 & 0.326 & 0.258 & 0.254 & 0.255 \\
$>6 \& \leq 10$ years & 0.271 & 0.252 & 0.268 & 0.253 & 0.241 & 0.291 \\
$>10 \& \leq 15$ years & 0.072 & 0.119 & 0.089 & 0.141 & 0.150 & 0.153 \\
$>15 \& \leq 20$ years & 0.030 & 0.043 & 0.037 & 0.037 & 0.041 & 0.043 \\
$>20$ years & 0.020 & 0.060 & 0.044 & 0.025 & 0.037 & 0.043 \\
Unemployment benefit & & & & & & \\
duration (days) & 188.2 & 591.3 & 108.7 & 216.9 & 603.0 & 121.7 \\
$\begin{array}{l}\text { Accum. unemployment } \\
\text { benefit }\end{array}$ & & & & & & \\
$=0$ days & 0.361 & 0.401 & 0.196 & 0.391 & 0.391 & 0.225 \\
$>0$ \& 1 year & 0.318 & 0.225 & 0.343 & 0.323 & 0.243 & 0.337 \\
$>1$ \& $\leq 3$ years & 0.211 & 0.241 & 0.262 & 0.197 & 0.214 & 0.257 \\
$>3$ \& $\leq 6$ years & 0.089 & 0.103 & 0.150 & 0.072 & 0.113 & 0.136 \\
$>6$ years & 0.022 & 0.030 & 0.048 & 0.017 & 0.039 & 0.046 \\
\hline Sample & 7,522 & 1,288 & 11,223 & 6,560 & 3,157 & 17,903 \\
\hline Sample (weighted) & 188,050 & 32,200 & 280,575 & 164,000 & 78,925 & 447,575 \\
\hline
\end{tabular}

